\title{
ДЕБЮТ
}

\author{
О.Н. Порва
}

\section{О СОВМЕЩЕНИИ КОММУНИКАТИВНЫХ РОЛЕЙ ШЕФ-РЕДАКТОРА И ВЕДУЩЕГО НОВОСТНОЙ ПРОГРАММЫ НА РЕГИОНАЛЬНОМ ТЕЛЕКАНАЛЕ (на примере ГТРК «Владивосток»)}

\begin{abstract}
Аннотация. В статье объектом исследования становится универсальная деятельность журналиста, а предметом исследования - специалист медиакоммуникационной сферы, который совмещает разные профессиональные амплуа, а конкретно - эфирную и редакторскую деятельность на телевидении. Проблема появления новых специалистов-универсалов в журналистике остаётся не изученной. Но является актуальной в связи с возрастающими требованиями к работнику телевидения, радио, газеты. Процесс совмещения редакторских функций и функций ведущего новостной программы рассматривается на примере региональной телекомпании ГТРК «Владивосток». Основным методом исследования является наблюдение, которое помогло зафиксировать факты поведения универсального специалиста в естественных условиях. Также использовался метод описательного и сравнительного анализа деятельности сразу нескольких специалистов-практиков, анализировались их функции и речевые стратегии. Научная новизна статьи заключается в выявлении нового типа универсальной деятельности, когда специалист становится и генератором идей, и агрегатором информационного потока, и ведущим новостного выпуска. $B$ статье указываются плюсы и минусы универсальной деятельности нового типа, а также предлагаются практические действия по её реализации. В ходе исследования был сделан вывод, что совмещение двух коммуникативных ролей амбивалентно: с одной стороны оно деструктирует функционал каждого из универсальных специалистов, но с другой стороны, порождает свободу интерпретации, поскольку возникает суверенность авторского начала.
\end{abstract}

Ключевые слова: медиакоммуникация, универсальность в журналистике, совмещение профессиональных амплуа, речевые стратегии, шефр-редактор, универсальный журналист, коммуникативные роли, адресат, коммуникативные навыки, ведущий новостной программы.

Abstract. The object of the present research is journalist's universal activity, the subject of the research is an expert in media communication who combines several professional roles, in particular, presenting news and acting as a chief editor. Appearance of these universal journalists still remains an understudied topic, however, it is quite an urgent topic due to the growing requirements for experts in TV broadcasting, radio broadcasting and newspaper publishing. The process of combining editor's and news presenter's functions are being analyzed based on the example of a regional state TV and radio broadcasing company 'Vladivostok'. The main research method used by the author of the article is observation that allowed to record facts of how a universal journalist behaves in his or her natural environment. The author has also used methods of descriptive and comparative analysis to analyze activities performed by a number of practical specialists, their functions and speech strategies. The scientific novelty of the article is caused by the fact that the author defines a new type of universal activity when a specialist is both an idea provider, informational flow aggregator and news broadcaster. The author of the article describes pluses and minuses of universal journalism and offers practical recommendations regarding performing such activity. In the course of the research the author makes a conclusion that this combination of two communicative roles is ambivalent: on the one hand, it destructs the composed function of each universal journalist, on the other hand, it creates free interpretation as a result of an actor's sovereignty.

Key words: communicative roles, universal journalist, Chief Editor, speech strategies, combination of professional roles, universalism in journalism, media communication, addressee, communicative skills, news presenter. 
$\mathrm{B}$ эпоху информационного общества средства массовой информации адаптируются к новым социальным и техническим условиям (например, переход на цифровое вещание) чрезвычайно быстро. Британский социолог Фрэнк Уэбстер подверг критическому анализу концепции, утверждающие переход общества в новую «постиндустриальную» эпоху. Ф. Уэбстер считает, что Д. Белл, М. Кастельс, Ж. Бодрийяр и другие авторы теории «информационного общества» приняли количественные изменения в СМИ за «информационную революцию». Не технологии изменили общество, а история человечества движется вместе с технической эволюцией. «Сами по себе технологические достижения лишены смысла и обретают значение только в социологическом аспекте» $[1$, с. 372]. Такое обоснование постепенного развития медиакоммуникации, позволяет рассмотреть последовательные внутрисистемные изменения в средствах массовой информации, в самой коммуникативной журналистской среде.

В 2016 г. впервые в России на базе «Высшей школы экономики» начнёт действовать новое направление подготовки - «Медиакоммуникация». Разработан современный профиль, объясняет руководитель образовательной программы Иосиф Дзялошинский, с оглядкой на потребности рынка. А рынку труда сейчас необходимы не просто журналисты, а специалисты иного профиля. Теперь это профессионал медиакоммуникационной сферы, знающий не только технологию создания сюжета или умеющий написать аналитическую статью (всё, конечно, зависит от специализации: радио, телевидение, печать), но также подготовленного с точки зрения технических и управленческих навыков. Этот универсальный специалист сможет найти себе применение в современной медиаиндустрии на стыке разных видов деятельности.

В аудиториях такого разнонаправленного профессионала сформировать сложно. Вся суть журналистского образования по сей день - в практической деятельности. Именно редакции первыми откликаются на изменения в сфере медиакоммуникации, они оперативнее ВУЗов берут курс на новые тенденции, подстраиваются под технические и технологические изменения, формируют новые кадры.

Журналистика, как отмечал теоретик С.М. Гуревич, изначально предполагает универсализм [2, c. 244]. Однако универсальность журналиста долгое времени выражалась в основном в тематической «всеядности». Т.е. конкретный корреспондент одинаково эффективно может работать с темами различных сфер общественной жизни. Связано это с тем, что в повседневной практике журналисту приходится отображать жизнь во всей её многогранно- сти и многообразии, используя все находящиеся в его распоряжении средства и формы. Универсалыпрактики появились в советских редакциях в 50-х гг. прошлого века.

В постсоветское время журналисты ещё более расширяют свою практическую деятельность. Работники СМИ начинают экспериментировать - пробовать себя в разных журналистских амплуа. Сегодня универсальность по должностному принципу можно рассмотреть с двух позиций:

1) универсальность «горизонтального типа» - совмещение двух или более профессий исполнительского класса. Например, журналист работает репортёром телевизионным и радийным одновременно или совмещает эфирную деятельность с корреспондентской;

2) универсальность «вертикального типа», объединяющая профессии по вертикали власти. Иначе говоря - эта должностная универсальность сочетает в себе функции исполнителя и управленца. Выражается в интеграции профессий шеф-редактора и ведущего программы.

Каждый из этих типов сформировался в российских редакциях, в основном в региональных компаниях. Не большие телевизионные станции не могут позволить себе обширный штат сотрудников. Экономические причины вынуждают руководство сокращать специалистов, распределяя невыполненную работу между оставшимися сотрудниками. Универсальность тематическая и универсальность «горизонтального типа» уже активно проникла в журналистский производственный цикл. Универсальность «вертикального типа», ассимилирующая две профессии шеф-редактора и ведущего программы, ещё на стадии становления. Тем не менее интенсивно меняющаяся медийная сфера предъявляет новые требования к российским редакциям и её специалистам. Уже сейчас шеф-редактору, отвечающему за работу всего коллектива и формирующего новостную программу, необходимо совмещать различные журналистские коммуникативные роли, как в редакционной, так и в массовой коммуникации, в том числе обладать техническими и управленческими навыками. Проблема появления новых специалистов-универсалов в журналистике остаётся не изученной. И тем более становится актуальной в связи с возрастающими требованиями к работнику телевидения, радио, газеты.

Если вернуться к недавно разработанной, но на практике уже действующей, технологии образования, сочетающей в себе управленческие, коммуникационные и технические умения, то, как было сказано выше, в редакции к таким специалистам можно отнести: ведущего программы и шеф-редактора. В статье будет рассматриваться должность шеф- 
редактора, так как этот специалист обязателен во всех филиалах Всероссийской государственной телерадиокомпании (в том числе в редакции ГТРК «Владивосток»), он является вторым лицом после главного редактора и руководит службой информации. Остальные редакторы назначаются по усмотрению руководителя.

На крупных федеральных каналах работают десятки редакторов: дневной, вечерний, помощник редактора, редактор-корректор, райтер и т.д. Замыкается эта профессиональная когорта на шеф-редакторе - специалисте, который несёт ответственность за программу. В региональных компаниях редакторский штат сокращён до минимума. На ГТРК «Владивосток» работают три шефредактора - Станислав Бабко, Елена Богданова и Ольга Порва. Они же ведущие программы новостей. Можно сказать, что это уникальный случай, когда в телекомпании все редакторы параллельно работают в эфире. Так, например, в ГТРК «Дальневосточная» в городе Хабаровск информационными выпусками на канале Россия-1 занимаются два шеф-редактора. Ведущими они не работают. Та же система и в Благовещенске в ГТРК «Амур». Однако, схожие практики универсальной деятельности «вертикального типа» всё же есть. Например, Иван Капсамун - ведущий программы «События недели» в хабаровском филиале также является и редактором своей программы.

С.М. Гуревич видит в стремлении к универсальности возрастающие требования к уровню профессионального мастерства журналиста. «Речь теперь идёт не только о необходимости уверенного владения большинством жанров публицистики и других типов публикаций, о сочетании оперативности информации с умением провести её глубокий анализ. И не только о сочетании универсальности журналиста с его специализацией. В современных условиях универсальность всё чаще оборачивается необходимостью соединять несколько специальностей» [3, с. 192].

«Каждый из нас, вступая в общение, выполняет определённую коммуникационную роль. Как в семье, так и в своей организации. Роль определяется тем, как мы распоряжаемся поступившей к нам информацией» [7, с. 34]. Это вполне применимо для медиакоммуникации. Корреспондент добывает информацию, собирает фактический материал на месте события. Шеф-редактор совмещает в себе противоположные направления, одновременно являясь генератором идей и агрегатором информационного потока. Ведущий в общем смысле посредник между редакционным коллективом и зрителем, его задача - передать информацию. Ведущий - понятие очень ёмкое и многоаспектное.
Журналист может вести развлекательное шоу, интеллектуальную передачу, быть комментаторам спортивного матча. Так как ГТРК «Владивосток» специализируется исключительно на новостном продукте, поэтому ведущий в нашем контексте это ведущий новостной программы.

Коммуникативная роль - это определённые функции, которые выполняют работники СМИ в процессе передачи информации. У шеф-редактора новостной программы их несколько:

- $\quad$ редакторская функция - вычитка текста сюжетов и сценариев ведущего на предмет языковых и стилистических ошибок, проверка логики текста и т.п.;

- организационно-управленческая функция (постановка задач корреспонденту, разработка синопсиса репортажа, планирование съёмок, верстание выпуска);

- контролирующая функция (оценка качества репортёрской работы: визирование репортажа, право наложения запрета на выход в эфир; определение места репортажа в выпуске);

- маркетинговая функция - продвижение новостного продукта, задача увеличить зрительскую аудиторию.

У ведущего новостной программы коммуникативная цель совершенного другого свойства - ведущий должен точно обозначить информационный повод и задержать зрителя у экрана. На Западе ведущего называют «анкормен», или человек-якорь. Слово «анкер» вошло в русский язык: например, в строительстве - это надёжная деталь крепления, на ней держится вся конструкция. В часах анкер определяет точность хода. Ведущий новостей выполняет несколько функций:

- коммуникативную (ведущий устанавливает связь между журналистом и аудиторией);

- $\quad$ информационную (удовлетворяет потребность людей получать точную, свежую, оперативную информацию);

- $\quad$ интегративную (ведущий объединяет, консолидирует аудиторию);

- социальную (ведущий ответственен за формирование мировоззрения аудитории, пропагандирует определённый образ жизни с соответствующим набором политических и духовно-нравственных ценностей).

Обозначенные функции необходимы для того, чтобы журналист независимо от его специализации мог точно определить цель своей работы, цель каждого выхода на экран. Когда специалист выступает в коммуникативной роли шеф-редактора, то он придерживается принципов социальной ответственности (профессиональная честность, уважение общественных интересов, способность 
предвидеть социальные последствия своих действий и т.д.). Журналист ответственен за свой репортаж, ведущий - за написанные им подводки, а шеф-редактор ответственен за всю программу, за каждое предложение корреспондента и за каждое слово ведущего. Эта функциональная особенность формируется не только на основе личных качеств работника ТВ, но и должностной инструкцией. В обычном режиме ведущий полагается на шефредактора, ведь именно руководитель даёт визу на текстовую информацию. Поэтому, в случае ошибки, будет виноват выпускающий редактор.

Шеф-редактор обязан нести ответственность за работу коллектива, а также чётко понимать и прогнозировать результаты телевизионного воздействия на массы людей. Безусловно, это приобретённое, сформировавшееся в ходе практической деятельности качество является базовым принципом в совмещении двух профессий. Коммуникативная роль ведущего обогащается редакторским свойством ответственности. Добиться такого эффекта иным способом невозможно. Это первый и самый важный плюс совмещения эфирной деятельности и деятельности шеф-редактора.

Совмещение профессиональных амплуа положительно сказывается на работе в кадре. Ведущий начинает чувствовать аудиторию непосредственно. Для эфирной деятельности - понимать своего адресата - важнейшая задача. Коммуникатор, ставящий цель добиться конкретной аудитории, должен определить её социальную ориентацию, позиции и интересы. В зависимости от этого подбирается форма информации, её объём и структура, а также средства её передачи.

Аудитория телеканала «Россия-1» компании ГТРК «Владивосток» (по данным «Гэллап-Медиа») состоит из мужчин (около 47\%), женщин (около 53\%). Примерный возраст: 35-54 года и старше. Однако помимо знания возрастных и гендерных данных своей аудитории, необходимо учитывать социальный статус зрителя. Чаще всего среди зрителей программы «Вести: Приморье» - домохозяйки, пенсионеры, учителя, врачи, в общем, работники бюджетной сферы. Дополнительно известно только то, что эта аудитория со средним или высшим образованием и средним уровнем дохода.

Начинающие журналисты отмеченные свойства (зависимость от зрителя, учёт характера аудитории, освоение коммуникативных навыков) не обнаруживают. Опытные шеф-редакторы - это те специалисты, которые выявляют информационные потребности граждан и всегда задают себе вопрос: «А было бы это интересно нашему зрителю?». И только, исходя из этой позиции, формируют выпуск и дают задания корреспондентам. Учитывая специфику своей аудитории, шеф-редакторы ГТРК «Владивосток» делают упор на социальные темы, темы сферы ЖКХ, здравоохранения, образования, культуры. Лишь треть выпуска отводится под экономику и политику. Таким образом, они учитывают социальную ориентацию адресата, их позиции и интересы.

В профессии журналист всегда выступает как адресант, как коммуникативный лидер. За что был укорён известным французским философом-постмодернистом Ж. Бодрийяром. Он упрекнул СМИ в односторонности и разрушенном диалоге: «...они являют собой то, что навсегда запрещает ответ, что делает невозможным процесс обмена... Именно в этом - их подлинная абстракция. И именно на этой абстракции основывается система социального контроля и власти» $[8$, с. 39]. Действительно, телевидение исключает прямой диалог между журналистом и зрителем (если только это не заранее подготовленные включения). Однако опосредованный диалог между ними всё же ведётся. Зритель отвечает телесобеседнику односложно: либо ему интересно и он смотрит программу, либо переключает на другой канал. Рейтинг, фиксирующий высокие просмотры передачи, говорит о подобранном к аудитории ключе, о построенном со зрителем диалоге. Подбирает этот ключ шеф-редактор.

Совмещение коммуникативных ролей шефредактора и ведущего - сложная конструкция, в первую очередь, в плане реализации многомерной деятельности. Определить волнующие общество темы, а затем и суметь представить их на экране - это работа глубокая, трансформирующая новостной выпуск и диалог со зрителем. Здесь нужно учитывать риски. Универсал испытывает колоссальные психологические нагрузки. Из-за того, что две коммуникативные роли специалист совмещает только во время ведения эфиров (иначе задачи шеф-редактора невозможно выполнять в полном объёме), то опасность ошибки возрастает именно в «публичной» части работы, что особенно тревожно. Одна из самых опасных ошибок (озвучивание ложной информации) может возникать из-за недостатка времени и снижения внимательности.

К минусам совмещения нужно отнести и размывание коммуникативных ролей. Во время эфирной деятельности обязанности шеф-редактора так или иначе распространяются на ведущего. Смена коммуникативных ролей происходит в одностороннем порядке - из роли ведущего выйти можно, а из роли шеф-редактора нет. Функции редактора выполняются ежедневно, вне зависимости от того, в каком амплуа на данный момент действует специалист.

Мы проанализируем новостные выпуски трёх шеф-редакторов также с семиотической точки зрения. «В семиотическом отношении телевизи- 
онный дискурс является полиструктурным, использующим знаковые коды иных систем: театра, кино, живописи, фольклора, массовой культуры, разговорной речи» [4, с. 156]. «Как термин семантики, код означает закон соответствия между планом выражения и планом содержания знака; кодом задаётся значимость знака, а интерпретатор эту значимость определяет, «расшифровывает», т.е. понимает знак» [5, с. 240]. Кодирование - это особый вид работы с информацией, когда в неё закладывается определённый смысл, а распознаётся он адресатом уже в ходе декодирования. Телевизионная журналистика - мультикодовая, она коррелирует в едином смысловом пространстве разнородные компоненты. Для современных СМИ характерна максимизация эффективности - стремление в каждую секунду эфирного времени вложить максимум информации. В связи с этим к «традиционным» знакам регулярно добавляются коды других систем. Если же очень общо разделить кодовую систему СМИ, то получатся две большие группы:

1. вербальный кодовый уровень;

2. визуальный кодовый уровень.

Каждый из них имеет сложные слои дифференциации. Вербальный кодовый уровень, по А.М. Шестериной, включает последовательность предъявления информации (эффект первичности и новизны), акценты или иллюзорные корреляции (суждения о других людях, часто повторяемая информация) [6, с. 122]. К вербальному кодовому уровню относятся также денотация (лексическое значение) и коннотация (ассоциации). Хотя денотативное и коннотативное значение проявляется и в визуальном коде. Например, видеосъёмка, на которой зафиксированы трудовые мигранты из Ближнего зарубежья, может распознаваться зрителем, как посягательство на территорию местных жителей. К визуальным кодам можно также отнести символы (например, флаг РФ или знак «купание запрещено»), динамическую картинку (ракурсы, цветовые гаммы, студийное оформление), а также определённые невербальные средства общения адресантов (жесты, мимика, одежда ведущего, архитектура студии).

В контексте исследования будет рассматриваться только языковой код редактора-ведущего, так как у специалиста совмещающего две коммуникативные роли работа именно с медиатекстом особенно показательна.

Основополагающим в медиакоммуникации является вербальный код. В журналистике, какую бы коммуникативную роль не взял на себя специалист, речь должна быть выстроенной и продуманной, а язык должен быть «как мировоззрение и даже как конкретное мнение, обеспечивающий максимум взаимного понимания во всех сферах идеологической жизни» $[9$, с. 12]. Язык становится выразителем социальных, политических и культурных процессов. Современный исследователь медиалингвистики Т.Г. Добросклонская выделяет несколько языковых процессов в СМИ: тенденцию к размыванию чётких стилевых границ; распространение норм разговорного стиля; тиражирование ошибочного речеупотребления; снижение речевой нормы за счёт употребления жаргонизмов и ненормативной лексики [10]. Замечен и антагонистический процесс. Распространение пресс-релизов и частое использование их, как основы для информационной заметки, ведёт к примитивизации профессии и к «обюрокрачиванию» медиаязыка $[11$, с. 1].

Основная функция языка - коммуникативная, цель которой - передать информацию, сообщить значимые сведения. Информирование для журналиста (оперативные сообщения, разного рода факты и события) - задача институциональная. При этом известно, что не вся информация, транслируемая СМИ, состоит из свежих, недавно появившихся сведений. Так, например, о наступлении масленичной недели говорит в эфире Станислав Бабко: «Широкий или даже разгульный четверг - день масленичной недели. Народ по традиции в этот день предавался всевозможным потехам, устраивались катания на лошадях и кулачные бои, которые завершались шумными пирушками». Информационная основа заметки: сегодня день масленичной недели. Больше в этом тексте новости для зрителя нет. А есть добавочные сведения о том, как раньше этот день отмечали на Руси. Слова: разгульный, потехи, пирушки - лексические единицы, вытесненные сегодня из активного речевого употребления. Архаизм С. Бабко использует для воссоздания древнерусского колорита и обращает внимание зрителей на традиции предков. Аудитории телеканала «Россия-1» масленичная тема интересна, так как она «народная», передаёт положительную эмоцию, подталкивает зрителей внести разнообразие в свою жизнь. Например, испечь блинов, прийти на массовый праздник.

В своей эфирной деятельности три автора используют определённые коммуникативные стратегии. «Коммуникативная стратегия - часть коммуникативного поведения или коммуникативного взаимодействия, в которой серия различных вербальных и невербальных средств используется для достижения определённой коммуникативной цели» [12, с. 256]. Современные исследователи выделяют несколько видов коммуникативных стратегий: информационную, регулятивно-воздействующую, эмотивную, интерпретирующую [13, с. 401]. Информационная стратегия обуславливается макроинтенцией (коммуникативная цель - сообщить 
массовой аудитории о случившемся факте, событии объективной реальности). Регулятивно-воздействующая или иначе манипулятивная стратегия выражается в желании адресанта скорректировать общественное мнение по конкретному событийному поводу. Если отправитель сообщения стремиться выразить себя с помощью эмоций, а коммуникативной целью становится пробуждение ответных чувств у адресата, то он пользуется эмотивной стратегией. Если же автор объясняет случившийся факт, основываясь на собственных взглядах, на своём опыте, мнении, подчиняет событие своей логике, то он прибегает к интерпретирующей стратегии. Выбор стратегии во многом зависит от профессиональных функций журналиста, в данном случае шеф-редакторов и ведущих. В связи с этим коммуникативные стратегии всех троих авторов схожи. Они в первую очередь стремятся информировать свою аудиторию, а уже потом конструировать информационные потоки, направлять мысли адресатов, возбуждать их эмоции, истолковывать и объяснять смысл случившихся событий.

Нужно признать, что к регулятивно-воздействующей и интерпретирующей стратегиям ведущие именно новостных программ обращаются редко, так как эти стратегии подразумевают аналитику, особый подбор и переработку фактического материала, развёрнутые объяснения и высказывание своего взгляда на событие. Жанровые и временные границы не могут позволить ведущему совместить все четыре стратегии одновременно в каждом выпуске. Поэтому основная стратегия, которую выбирают шеф-редакторы - информационная, но при этом с максимально точно проведённой эмоциональной линией. В то время как простые ведущие часто концентрируются на себе, стараясь вставить в ограниченное информационное поле свое не всегда уместное мнение, соответственно, смешивая речевые стратегии, и, таким образом, создают информационные помехи адресату.

Итак, схожесть выбранных стратегий объясняется коммуникационными целями шеф-редакторов. Во время эфирной деятельности они пользуются своими индивидуальными профессиональными инструментами. Относится к этому инструментарию и тактика, в данном случае - совокупность практических приемов. Наиболее характерные черты стиля каждого из авторов, их тактические приёмы заметны в написанных ими заголовках или анонсах. Это краткая информация, обычно не выходящая за рамки четырёх предложений. Главная задача анонса - привлечь внимание зрителя, заставить его смотреть следующую программу или дождаться выхода в эфир интересного сюжета в этом выпуске. Для рассмотрения маркеров авторского начала в нашем контексте чаще всего будет осмысливаться именно заголовок, ещё и потому, что в нём нужно совместить интригу и корректность, обойтись без «кричащих» слов жёлтой прессы, а вместо этого предложить альтернативную нетривиальную речевую конструкцию.

Используя информационную стратегию, ведущие-редакторы прибегают к следующим тактическим приёмам. Во-первых, каждый из представленных специалистов стремится к дескриптивной, т.е. адекватной, достоверной информации. «Ha дорогах Владивостока можно заметить большое количество нарядов ДПС. Это обязательные меры безопасности. Ведь в столииу Приморья прибыли более трёх тысяч участников из 26 стран» [Порва. 02.09.15]. "Дорожники завершают работы на очередном участке трассы «Владивосток - Находка - порт Восточный». За плечами строителей уже возведение восьми мостов и четырёх ж/д путепроводов» [Бабко. 11.03.16]. «Двух фальшивомонетчиков задержали в Приморье. Злоумышленники сбывали липовые купюры в магазинах мелкой розницы и торговых киосках Спасска и Владивостока» [Богданова. 21.03.16]. Дескриптивная информация описывает действие максимально правдиво и наглядно. Дескриптивность характеризует отношение текста, как продукта речи с действительностью, т.е. эта информация семантически адекватна реальности и подразумевает строгое, но при этом полное, открытое описание событий. Ведущий, совмещающий и редакторскую деятельность, всегда задаст вопрос о причинах события, рассмотрит процесс в контексте, что обычные ведущие часто выпускают из поля зрения, надеясь на уже подготовленный, проверенный текст.

Следующая позиция, которой придерживается шеф-редактор и переносит это знание на эфир - это как раз фактологическая информация. Определение факта, его выявление и уточнение, фиксируется во время подготовки к выпуску. Ещё одна коммуникативная тактика ведущего-редактора - это использование интерсоциальной информации, т.е. информации значимой для всех слоёв общества. Чёткая осознанная коммуникативная цель позволяет выявить в любой сфере деятельности человеческую историю, добавиться живости в текст, распознать социальную сущность рассматриваемого явления. Так, например, в Приморье заработал сайт, на котором можно выставить оценку любому представителю муниципалитета. Зная, что множество приморцев хотели бы высказать своё мнение по поводу власти и скорректировать их работу, Станислав Бабко пишет следующий анонс: «Уволить чиновника за бездействие. Как сделать это вполне официально, да еще и не выходя из дома? Новый 
сайт заработал в Приморье» [Бабко. 01.02.16]. И уже в вечернем прайме Станислав меняет заголовок, привлекая внимание зрителей возможностью повлиять на работу народных избранников: «Сайт «Голос 25», призванный стать инструментом народной власти, принимает первые голоса приморцев. К этому часу проголосовало уже полсотни человек» [Бабко. 01.02.16]. Или вот так проанонсировала вечерний выпуск ведущая О. Порва: «C января 2016-го года, приморская генерация ДГК поновому собирает долги за тепло. Начислять пеню для Управляющих компаний, например, начинают с первого месяца задержки. Тонкости нового штрафного механизма, а также важная и полезная информация про энергетиков и коммунальщиков - в вечерних выпусках программы «Вести-Приморье» [Порва. 25.01.16]. Таким образом, в выпусках делается акцент на интерсоциальной информации.

И всё же тактические приемы у трёх ведущих не всегда совпадают. Если вернуться к фактологической информации. Факты могут быть разными. Из всего объёма текста в свою подводку ведущий может взять общие сведения, а может вывести не основные данные, а информацию дополнительного характера и на них заострить внимание. Так, например, Елена Богданова перерабатывает сухой пресс-релиз от следственного комитета о судебном разбирательстве и в начало ставит информацию об инциденте на заседании: «Закусил страницами своей же криминальной биографии. Один из арестованных в СИЗО Владивостока съел часть дела» [Богданова. 14.01.16]. Интересный факт в данном случае сразу же вынесен в начало. А вот ведущая Ольга Порва интересную историю опустила в середину информационного текста, лишь заинтриговав в начале зрителя: «И снова вернёмся к теме Восточного экономического форума. Уже с пикантной историей... Одной из главных звёзд ВЭФ стала голливудская актриса и зоозащитница Памела Андерсон» [Порва. 02.09.16]. И на этом фоне довольно прямолинейно пишет заголовки Станислав Бабко: «Продажи золота, шоколада и косметики во Владивостоке бьют все рекорды. Постарались китайцы» [Бабко. 03.02.16].

Одна из самых сложных форм журналистского мастерства - стимуляция ассоциативной памяти у зрителя, сопоставление события с фактами из прошлого, сопряжение. Например, О. Порва отмечает: «...кинодива прибыла в Приморье накануне. Как с неудовольствием отметили очевидцы, голливудская актриса приехала во Владивосток в тёплом закрытом пальто» [Порва. 02.09.16]. Казалось бы, странная деталь - предмет одежды. Если бы так было сказано, допустим, об Ирине Родниной или Ольге Голодец и ещё множество женщин могут пополнить этот список - запахнутое пальто было бы лишней и не нужной информацией. Но поскольку речь шла о Памеле Андерсон, которая известна всему миру своей исключительной фигурой, то всё становится понятным. Автор подразумевает, что зритель знает звёздную деятельность кинодивы. Таким образом, одно предложение передало не только описание стиля, но и глубокое разочарование поклонников её таланта и красоты. Этот подход можно разобрать с семиотической точки зрения, разделив отношение между знаком и его референтом, на детонацию и коннотацию. Денотация - буквальное значение знака, символа, а коннотация указывает на его социокультурные и персональные ассоциации. Так, на денотативном уровне П. Андерсон - это актриса, а на коннотативном уровне мы ассоциируем эту женщину с такими чертами, как сексуальность, открытость, эпатаж.

С помощью символов редакторы-ведущие кодируют разного рода информацию. Осознавая свою социальную позицию, ориентируясь на Закон РФ и механизмы воздействия на аудиторию, они придерживаются демократических норм и контролируют одну из самых проблемных тем - межнациональную. Конфликтные ситуации этой сферы крайне редко редакторы пропускают в эфир, чтобы не усиливать межэтническую напряженность. Если же в программе эта тема всё-таки звучит, то чаще всего, как положительная новость. «Евреи, татары, удэгейщы, украинцы и белорусы за одним столом. На третий Конгресс народов приехали сотни участников!», - пишет в своем заголовке О. Порва [Порва. 02.11.16]. Всячески подчёркиваются спортивные и культурные события такими речевыми оборотами, указывая на масштабность и коллективизм, сплочённость приморцев. Часто применяются следующие речевые обороты: «со всего Приморского края собрались», «даже из глубинки откликнулись», «Владивосток стал центром массового сбора приморских пловцов» и т.п.

Вообще шеф-редакторы ГТРК «Владивосток» довольно часто подчёркивают статус портового, активного города, занимаются созданием образа края, как непосредственного участника Всероссийских и международных событий. Обязательно добавляют в картину дня такие информационные поводы, как швартовка круизного лайнера, международные конференции, круглые столы, приезд иностранных учёных и т.п. Е. Богданова тоже не упускает случая именно эту тему поднять в начало выпуска: «Жители Екатеринбурга, Москвы, Прибалтики и даже Новой Зеландии загадывали новогодние желания в Арсеньеве» [Богданова. 14.01.16].

Эмотивная стратегия выражается чаще всего в речевой тактике - формирование эмоциональ- 
ного настроя. Было уже отмечено, что к этому типу стратегий трое шеф-редакторов тоже прибегают. «Основная цель говорящего при реализации экспрессивно-апеллятивной (эмотивной) стратегии - выразить свои чувства, коммуникативные интенции, предпочтения, настроения в отношении коммуникативной ситуации в целом. Диалоги в рамках экспрессивно-апеллятивной стратегии демонстрируют регулярный характер модальных реакций. В фокусе этих реакций находятся не факты или знания говорящих, как в информационно-аргументирующем диалоге, а их мнения, интенции, мотивы» [13, с. 402].

Безусловно, журналист, как и ведущий, так и шеф-редактор обязаны быть объективными. Но порой субъективная оценочность легко эксплицируется из мимикрии под объективность. Языковой код передаёт адресату сигнал о нестандартном поведении ведущего информационной программы. В этом случае журналист использует эмотивный тактический приём: имплицитно выразить своё субъективное мнение. Часто это выливается в лёгкую форму иронии. Например: «Не всё так радужно, как в отчёте! Почему рассказывая об успехах своей администрации, глава Арсеньева умолчал о проблемах?» [Богданова. 24.03.16]. Уже в вечернем выпуске автор переписывает заголовок, но ироничный тон сохраняется: «Глава Арсеньева Александр Дронин победно отчитался перед горожанами об успехах и достижениях администрации города, разумеется под его руководством» [Богданова. 24.03.16]. Дефиниции: «отчитался», «умолчал» носят изобличающий характер, говорят о негативной оценке ведущего действий арсеньевской Администрации. Иронические замечания делает и О. Порва: «Идеи идеями, но убеждать иностранных инвесторов придётся не столько масштабами замыслов и полётом мысли, сколько реальными делами» [Порва. 02.09.15]. Здесь мнение и вовсе высказано прямо.

Проанализировав коммуникативные роли, стратегии и речевые тактики трёх ведущих и одновременно шеф-редакторов нами была выявлена существенная особенность. Во-первых, универсалы вертикального типа свободно используют в своих работах не только положенную по жанру информативную, но и эмотивную стратегию. Простые ведущие тоже используют эти стратегии, но новость ими не осмысливается на глубоком эмпирическом уровне.

Во-вторых, крайне важным фактором в подготовке к эфиру для них является дискриптивная и фактологическая информация. Опять же эти коммуникативные цели сформированы жанровой особенностью информационных выпусков. И в-третьих, работая ведущими, они не оставляют в стороне функционал шеф-редактора, т.е. выполняют параллельно редакторскую, управленческую, маркетинговую функции. Главная цель универсалов вертикального типа - продвижение своего новостного продукта в информационную среду.

Интересен регулярно происходящий случай, когда два шеф-редактора ГТРК «Владивосток» работают в одной смене, но один действует в роли ведущего. В данном случае дежурный шеф-редактор часть своей нагрузки и ответственности передаёт коллеге. Именно в этом тандеме происходит интеграция профессиональных амплуа, когда специалист продолжает выполнять должностные обязанности, оставаться в глазах коллектива шефредактором, а в реальной деятельности - ведущим. Коллектив не готов к быстрой смене функциональной деятельности конкретного специалиста. Таким образом, профессиональная роль шеф-редактора существует перманентно.

Автор становится и идейным вдохновителем, и модератором, т.е. авторство выходит за границы одной, конкретной коммуникативной роли. Происходит ассимиляция - процесс уподобления, когда разные профессии, различающиеся внутренней организацией, функционалом, ценностной ориентацией, соединяются. В этом случае нужно говорить о потере самоидентификации, о том, что утрачивается ощущение своей профессиональной специализации, размываются границы коммуникативных ролей.

С другой стороны, шеф-редактор, не отстраняясь от практической журналистской деятельности, продолжает развивать свои навыки. Смена специализации приводит не только к необходимости получения новых знаний, но и к формированию новых личностных черт. Ещё не так давно полифункциональность, вообще как явление не существовало, сегодня становится требованием времени. В связи с этим совмещение двух коммуникативных ролей амбивалентно: с одной стороны оно деструктирует функционал каждого из универсальных специалистов, добавляя социальной ответственности, требует максимальной объективности и создаёт дополнительные профессиональные задачи. Но с другой стороны, порождает свободу интерпретации, поскольку расширяется презумпция автора, возникает суверенность авторского начала.

Агрегация коммуникативных ролей ведущего и шеф-редактора - явление в журналистике пока не повсеместное. Однако у нас есть предположение, что дальнейшая трансформация редакторской и эфирной деятельности ведущих продолжится. В связи с этим, рассмотренные в статье стратегии помогут журналистам эффективнее выполнять свои профессиональные функции. 


\section{Филология: научные исследования 4(24) • 2016}

\section{Список литературы:}

1. Уэбстер Ф. Теории информационного общества. М.: Аспект Пресс, 2004. 400 с.

2. Гуревич С.М. Основы научной организации журналистского труда: учебное пособие для студ. вузов, обуч. по спец. «Журналистика». М.: Высшая школа, 1987. 303 с.

3. Гуревич С.М. Экономика отечественных СМИ. М.: Аспект Пресс, 2004. 288 с.

4. Мартыненкова М.Г. Сравнительный анализ телевизионных новостных выпусков (русская, английская, французская версии телеканала «Euronews») // Политическая лингвистика. 2013. № 2 (44). С. 155-158.

5. Ковшова М.Л. Семантика и прагматика фразеологизмов (лингвокультурологический аспект): Дисс. … д-ра филол. наук. М., 2009. 654 с.

6. Шестерина А.М. Психология журналистики. Воронеж: Изд-во Воронеж. гос. ун-та, 2010. С. 45.

7. Зверинцев А.Б. Коммуникационный менеджмент. Рабочая книга менеджера РR. СПб.: Изд-во Буковского, 1995. 267 с.

8. Бодрийяр Ж. Реквием по масс-медиа // Поэтика и политика. Альманах Российско-французского центра социологии и философии Института социологии Российской академии наук. СПб.: Алетейя, 1999. С. 193-226.

9. Бахтин М.М. Собр. соч. Т. 3. Теория романа (1930-1961 гг.). М.: Языки славянских культур, 2012.880 с.

10. Добросклонская Т.Г. Медиалингвистика: системный подход к изучению языка СМИ. М.: Флинта: Наука, 2008.264 с.

11. ШмелеваT.В.Прессрелизкакугрозамедиатексту.[Электронныйресурc]URL:http://jf.spbu.ru/conference/6081/6086. html.

12. Зелинский С.А. Информационно-психологическое воздействие на массовое сознание. Средства массовой коммуникации, информации и пропаганды - как проводник манипулятивных методик воздействия на подсознание и моделирования поступков индивида и масс. СПб.: Издательско-Торговый Дом «СКИФИЯ», 2008. 407 с.

13. Олешков М.Ю. Интенция как основа коммуникативной стратегии в институциональном дискурсе // Русский язык: исторические судьбы и современность: III Международный конгресс исследователей русского языка (Москва, МГУ им. М.В. Ломоносова, филологический факультет, 20-23 марта 2007 г.): Труды и материалы / Сост. М.Л. Ремнева, А.А. Поликарпов. М.: МАКС Пресс, 2007. С. 401-402.

\section{References (transliterated):}

1. Uebster F. Teorii informatsionnogo obshchestva. M.: Aspekt Press, 2004. $400 \mathrm{~s}$.

2. Gurevich S.M. Osnovy nauchnoi organizatsii zhurnalistskogo truda: uchebnoe posobie dlya stud. vuzov, obuch. po spets. «Zhurnalistika». M.: Vysshaya shkola, 1987. $303 \mathrm{~s}$.

3. Gurevich S.M. Ekonomika otechestvennykh SMI. M.: Aspekt Press, 2004. $288 \mathrm{s.}$

4. Martynenkova M.G. Sravnitel'nyi analiz televizionnykh novostnykh vypuskov (russkaya, angliiskaya, frantsuzskaya versii telekanala «Euronews») // Politicheskaya lingvistika. 2013. № 2 (44). S. 155-158.

5. Kovshova M.L. Semantika i pragmatika frazeologizmov (lingvokul'turologicheskii aspekt): Diss. ... d-ra filol. nauk. M., 2009. $654 \mathrm{~s}$.

6. Shesterina A.M. Psikhologiya zhurnalistiki. Voronezh: Izd-vo Voronezh. gos. un-ta, 2010. S. 45.

7. Zverintsev A.B. Kommunikatsionnyi menedzhment. Rabochaya kniga menedzhera PR. SPb.: Izd-vo Bukovskogo, 1995.267 s.

8. Bodriiyar Zh. Rekviem po mass-media // Poetika i politika. Al'manakh Rossiisko-frantsuzskogo tsentra sotsiologii i filosofii Instituta sotsiologii Rossiiskoi akademii nauk. SPb.: Aleteiya, 1999. S. 193-226.

9. Bakhtin M.M. Sobr. soch. T. 3. Teoriya romana (1930-1961 gg.). M.: Yazyki slavyanskikh kul'tur, 2012.880 s.

10. Dobrosklonskaya T.G. Medialingvistika: sistemnyi podkhod k izucheniyu yazyka SMI. M.: Flinta: Nauka, 2008.264 s.

11. Shmeleva T.V. Press reliz kak ugroza mediatekstu. [Elektronnyi resurs] URL: http://jf.spbu.ru/conference/6081/6086. html.

12. Zelinskii S.A. Informatsionno-psikhologicheskoe vozdeistvie na massovoe soznanie. Sredstva massovoi kommunikatsii, informatsii i propagandy - kak provodnik manipulyativnykh metodik vozdeistviya na podsoznanie i modelirovaniya postupkov individa i mass. SPb.: Izdatel'sko-Torgovyi Dom «SKIFIYa», 2008. 407 s.

13. Oleshkov M.Yu. Intentsiya kak osnova kommunikativnoi strategii $v$ institutsional'nom diskurse // Russkii yazyk: istoricheskie sud'by i sovremennost': III Mezhdunarodnyi kongress issledovatelei russkogo yazyka (Moskva, MGU im. M.V. Lomonosova, filologicheskii fakul'tet, 20-23 marta 2007 g.): Trudy i materialy / Sost. M.L. Remneva, A.A. Polikarpov. M.: MAKS Press, 2007. S. 401-402. 